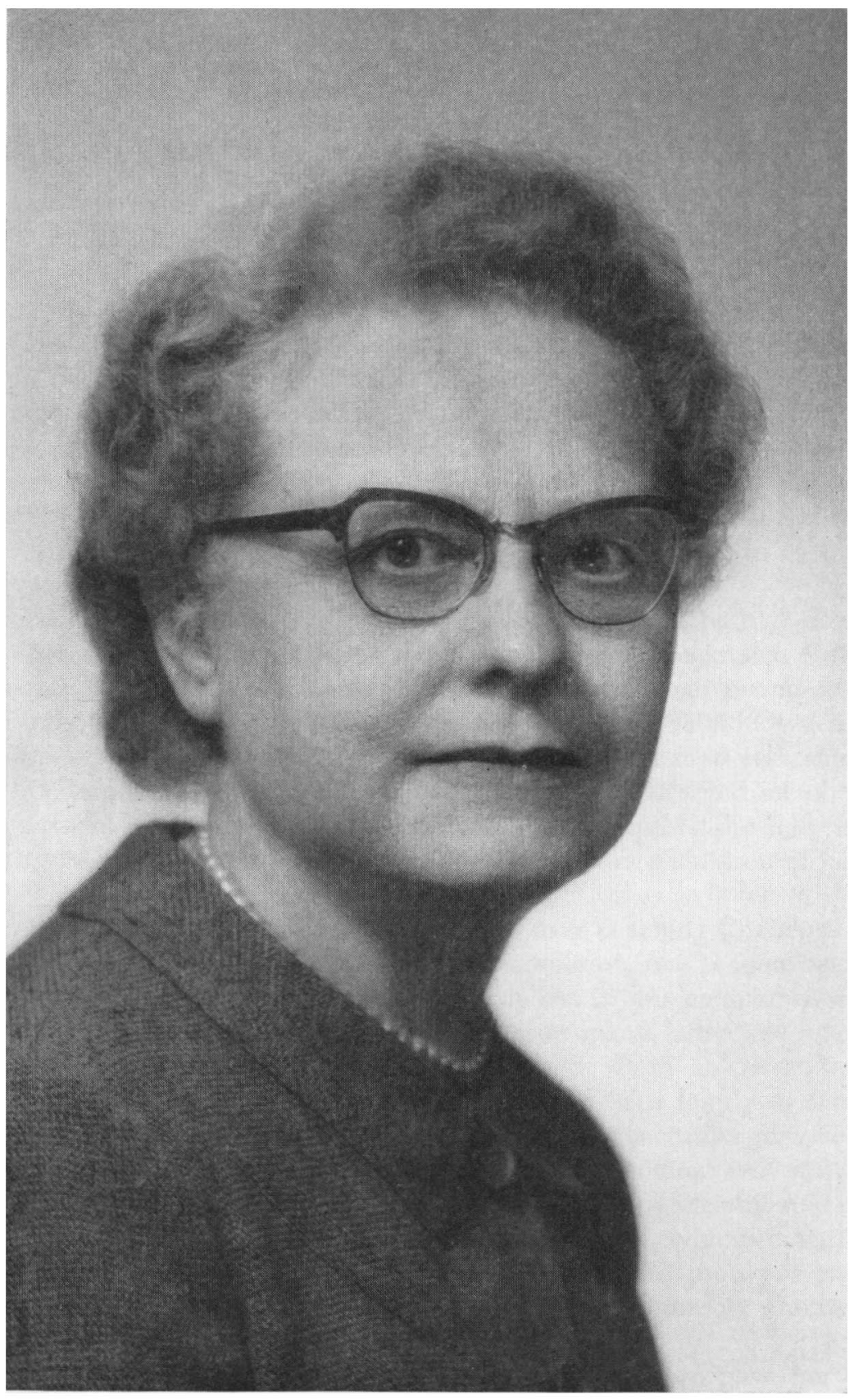

HENRIETTA M. LARSON

Photo by Bradford Bachrach 


\section{Henrietta M. Larson: \\ An Appreciation}

In 1959 Harvard University, for the first time, appointed a woman to a full professorship at its Graduate School of Business Administration. The new Professor of Business History, Henrietta Melia Larson, was no stranger to her colleagues at the institution where she had worked since 1928 nor to the business historians of the United States. She was known as an outstanding scholar in her field and widely respected for her attainments. At this period of her semiretirement from Harvard it seems appropriate to honor her by dedicating to her this issue of the Business History Review and by evaluating the contributions which she has already made to her profession.

The assignment to write this dedicatory essay is both a deep pleasure and a difficult task for two people who have known Henrietta Larson and her family intimately for more than twenty-five years. We have worked with her closely, valued her calm judgment, and appreciated her unstinting gift of time and ideas to us and many other students. We have known her further as a devoted member of a close-knit family; in her home for several years she had, as they were completing their education, one or more children of her widower brother.

At the conference on "Business History as a Teaching Challenge," the results of which are reported in this volume, one session dealt with the training of researchers and teachers in this comparatively new field. In the case of Henrietta Larson many influences were at work and the training was broad indeed. Born at Ostrander, Minnesota, in 1894, she grew to womanhood in a family of four girls and one boy. Her parents were only one generation removed from Norwegian forefathers, whose Lutheran religion and native language became an integral part of her heritage. (She still speaks Norwegian fluently.) Tales of two grandmothers, widowed early with large families to rear, acquainted her with the problems and the achievements of those who lived on the Minnesota frontier from the 1850 's to the 1880 's.

More immediately, the parents of Henrietta Larson gave her a living example of self-reliance coupled with willingness to work 
with others. Her father began his adult life as a storekeeper, turned to farming for a time, then diversified his activities by persuading fellow farmers to join him in incorporating a bank and organizing three cooperative enterprises - a creamery, a grain elevator, and a cattle shipping association. Always a strong advocate of cooperatives and farmers' institutes, he consistently voted the Republican ticket and to the day of his death (1936) maintained that the farmers could and should handle their own problems without recourse to governmental aid. His helpmate, Henrietta's mother, was quietly active in community affairs and eagerly devoted to assuring her children a good education. That she realized her goal is indicated by the fact that all five of her children who lived to maturity graduated from St. Olaf College and three daughters won doctorates. ${ }^{1}$

To her family heritage Henrietta Larson added an education as broadly based as any present-day historian could desire. After graduating from high school in Northfield, Minnesota, in 1914, she attended St. Olaf College in the same town, majoring in English Literature and minoring in both Chemistry and History. A year of teaching high school at Wheaton, Minnesota, formed an interlude prior to graduate study at Columbia University, originally intended as preparation for admission to the New York School of Social Work. At Columbia and the New School for Social Research, in courses and seminars on Social Theory, Social Institutions, Principles of Sociology, Statistics, Labor Problems, History of Representative Government in the United States, and Social and Political History of Modern Europe, the future business historian sat at the feet of such famous professors as Tenney, Giddings, Chaddock, Moore, Seager, Beard, and Hayes. Columbia awarded her an M. A. in Sociology in 1920.

At this time the young student from Minnesota decided to continue her graduate work at Columbia - in History. Dixon Ryan Fox gave her a taste of Social History of the United States, B. B. Kendrick taught her the history of the country from 1865 to 1900 in the Simons-Beard tradition, W. R. Dunning led her through a seminar on American Political Theory, W. R. Shepherd introduced her to the history of Latin America, and F. J. E. Woodbridge leavened the whole with an introduction to Philosophy. By passing her general examination in May, 1921, with Carlton J. H. Hayes

\footnotetext{
1 The other two academic sisters are: Agnes Larson, Ph.D., Radcliffe College, author of White Pine Industry in Minnesota (Minneapolis, University of Minnesota Press, 1949) and recently retired as head of the History Department of St. Olaf; and Nora Larson, Ph.D., University of Minnesota, now a member of the Biology Department at St. Olaf College.
} 
presiding, Henrietta Larson was admitted to candidacy for the Ph.D. in History. Giddings, it is reported, said it was a brilliant examination; a measure of her humility is that she still suspects that the examiners were easy on her; she was young, shy, and golden haired.

A year of teaching history, economics, and political science at Augustana College, Sioux Falls, South Dakota, in 1921-1922 amounted to no more than a break in stride for the new candidate for a Ph.D. She decided to write her dissertation on wheat marketing and began her research. The next fall she entered the University of Minnesota, where she stayed two years as a Teaching Fellow, instructing in Modern World under Guy Stanton Ford and A. C. Krey the first year and in American History under G. M. Stephenson and L. B. Shippee the second. At the same time she fortified her knowledge of history and economics by taking courses on the History of the West with Solon J. Buck, Money and Banking with G. W. Dowrie, Value and Distribution with F. B. Garver, Agricultural Marketing with L. D. H. Weld, and Economic History with N. S. B. Gras.

In 1926 the young Minnesotan reached the end of her long formal training. While at the University of Minnesota she had used every spare minute to do research on the history of wheat marketing; she spent long hours at the Minnesota Historical Society and interviewed many men familiar with the early grain business - from steamboat captains to flour millers. She had no luck getting original documents of elevator or milling companies but gained access to many records of railroad corporations. Having taken time off to write, except for three months of teaching at Mankato Teachers College as a substitute for her ill sister Agnes, Henrietta completed her dissertation in the fall of 1925, had it accepted at Columbia, revised it, sent it to press, passed her final examination in February, 1926, and received her doctorate in June of that year. Her dissertation, The Wheat Market and the Farmer in Minnesota, 1858-1900, was published the same year and is still regarded as the authority in its field.

Meanwhile, Henrietta Larson had resumed her teaching career. First, she spent a year at Bethany College, Lindsborg, Kansas (1925-1926); then followed two busy years in Carbondale at Southern Illinois University (then Southern Illinois Normal University). She taught American History and, part of the time, an extension course in Principles of Economics. At Carbondale she had the unique experience of being the first Ph.D. in the whole institution. For that reason she was assigned administrative tasks designed to upgrade the standards of the school. 
While worrying about the fact that her administrative duties were interfering with her first love - teaching-Henrietta was faced with the biggest decision of her life. At the request of Dean Wallace Donham, Professor Gras had agreed in 1927 to go to the Graduate School of Business Administration at Harvard to start a course and a program of research in business history. He now asked his erstwhile student at Minnesota to join his group as a Research Associate. She knew that, although she respected his original and probing mind, she did not share several of N. S. B. Gras's beliefs, and that, if she accepted the invitation, she would probably have slight chance to teach. Furthermore, acceptance would involve a reduction of one third in her salary! Assured by Professor Gras that her later salary and rank would be determined by the quality of her work, and challenged by the opportunity to share in developing a new field with a man having a broad concept of history, Henrietta submerged her misgivings and accepted the offer to come to Harvard.

Life at the Harvard Business School proved stimulating and exciting, even almost frenetic at times. The energetic Henrietta reveled in working with the Gras group-discussing the course in Business History and the preparation of cases for it, talking with researchers interested in topics ranging from the medieval scene to twentieth-century United States, and conducting her own research on a private banker, Jay Cooke. She also published three essays in the Journal of Economic and Business History, ${ }^{2}$ a quarterly periodical inaugurated in 1928 with Edwin F. Gay as editor and N. S. B. Gras as managing editor.

In less than four years, however, the pleasant picture began to have some darker hues. Professor Gras disagreed with Professor Gay over editorial policy for the Journal of Economic and Business History; Gras became sole editor in 1931, but financial support of publication soon (1932) evaporated and its publication ceased. Curtailment of funds as a result of the Great Depression next forced a cutback in the general research program, although in 1931 the Harvard Studies in Business History was started with $\mathrm{K}$. W. Porter's John Jacob Astor, and other projects were soon begun.

In spite of the limited financial resources, Henrietta worked unceasingly with other scholars to build up a body of reliable information on Business History. Under the editorship of Professor Gras, she published Jay Cooke, Private Banker in 1936. Her contribution

2 "A Medieval Swedish Mining Company," vol. II, no. 3 (May, 1930), pp. 545-559; "S. \& M. Allen - Lottery, Exchange, and Stock Brokerage," vol. III, no. 3 (May, 1931), pp. 424-445; "E. W. Clark \& Co., 1837-1857," vol. IV, no. 3 (May, 1932), pp. 429-460. 
here was not only that she portrayed Cooke as an innovater in financing the Civil War, and frankly revealed his difficulties as a pioneer in financing large railroad projects, but that she contributed a great deal to general knowledge on the history of investment banking. That same year K. W. Porter added The Jacksons and the Lees: Two Generations of Massachusetts Merchants, 1765-1844 to the Studies. A year later Professor Gras himself produced The MassachusettsFirst National Bank of Boston, 1784-1934, and in 1939 Ralph M. Hower published The History of an Advertising Agency: N. W. Ayer \& Son at Work, 1869-1939.

By the end of the 1930's Henrietta had helped to establish Business History on a firm footing. She was co-author with N. S. B. Gras of the Casebook in American Business History, published in 1939. This book, the first body of assembled data on the subject, was the culmination of the work and experience of more than a decade. ${ }^{3}$ It demonstrated, along with Professor Gras's Business and Capitalism (published the same year), the character, depth, and range of the new field. Soon a few scholars in other institutions started courses on the history of business, relying heavily on the two new books. Other economic and general historians began using the Casebook for supplementary reading and class discussion.

At the same time, the Business History group had become relatively isolated. This situation was partly a function of limited finances, partly because of Professor Gras's definition of the new field as a history of business administration in action, partly a result of personality conflicts, and partly a consequence of the lack of interest on the part of general as well as economic historians. Other elements were the suspicions that many historians held about favorable evaluation of business activities and the fact that the pioneer Business History group was located at a graduate school of business administration. Henrietta lamented this isolation but found it extremely difficult to change.

In spite of the difficulties of those years, Henrietta feels great pride in having worked with Professor Gras during the 1930's. " $\mathrm{He}$ was extremely creative," she recently observed. "He gave no end of time to those of us who worked with him. He was usually way ahead of us in his thinking. Sometimes, of course, I disagreed with him, as on his emphasis on the supply of gold as the principal generating factor in the cycle and the secular trend. But he did see the importance of the administrator in business, particularly as a policy-

\footnotetext{
${ }^{3}$ See also Henrietta M. Larson, "A China Trader turns Investor - a Biographical Chapter in American Business History," Harvard Business Review, vol. XI (April, 1934), pp. $345-358$.
} 
maker. Where else would you have found a scholar with so fine a grounding in economic history and so close an acquaintance with business? I think his work on types of businessmen and even stages may eventually be found to be more valid and useful than at present, particularly as we get away from as rigid a structure as seemed to develop in Gras's mind later. In any event, he treated the businessman as a creative factor and thus not only gave greater reality to history but contributed to the breaking of the hold that economic determinism had on much historical writing. I think this philosophical result is much more important than his stages."

In 1938 Henrietta had begun her long editorship of the Bulletin of the Business Historical Society. ${ }^{4}$ In that capacity she wrote many unsigned as well as signed articles for the periodical. ${ }^{5}$ One of the more important ones was "Some Unexplored Fields in American Railroad History," given at the meeting of the Mississippi Valley Historical Association at Lexington, Kentucky, in the spring of 1942. At the same session those historians interested in the history of railroads organized the informal Lexington Group that is still active.

Another significant article by Henrietta appeared in the Harvard Business Review in the spring of 1944. It was entitled "Danger in Business History." Starting to write a review of The Age of Enterprise by T. C. Cochran and William Miller, Henrietta produced an extensive analysis of the state of Business History in the United States. In that essay she mentioned that there was not a single comprehensive historical study of a large corporation in the country. That statement caught the eyes of officials of Standard Oil Company (New Jersey) who were then pondering the possibility of a history of their firm. They asked Professors Gras and Larson to consider writing a multi-volume history of the company.

For Henrietta this request of Jersey Standard provided a second turning point in her career. To get an estimate of the feasibility of the proposed project, she undertook to make a survey of the records of the Jersey Company and its affiliates. With some assistance, she completed the task in eleven months; then it was concluded that

The Bulletin of the Business Historical Society, Inc. was started in June, 1926, under the editorship of the secretary of the society, Frank C. Ayres. From February, 1936, it was edited for two years by Ralph M. Hower. Henrietta Larson acted as editor from February, 1938, through its last issue of December, 1953. The Business History Review was first published in March, 1954.

5 "The Armor Business in the Middle Ages," vol. XIV (Oct., 1940), pp. 49-64; "Capitalism - Concepts and History," vol. XIV (April, 1942), pp. 39-42; "Some Unexplored Fields in American Railroad History," vol. XVI (Oct., 1942), pp. 69-79; "The Social Implications of Business Administration: Past and Present," vol. XVII (Feb., 1943), pp. 27-31; "An Early Industrial Capitalist's Labor Policy and Management," vol, XVIII (Nov., 1944), pp. 132-141; "Business Men as Collectors," vol. XVIII (Dec., 1944), pp. $162-170$. 
a scholarly history of Standard Oil Company (New Jersey) could be produced on the basis of extant records and published materials. By the spring of 1947 she had aided Professor Gras in forming the Business History Foundation, Inc., a New York corporation, to sponsor the project at hand as well as similar ones in the future. Henrietta was elected a Trustee and Treasurer of the Foundation, helped select the authors and researchers for the Standard Oil volumes, and became the field supervisor of the project.

While helping to plan the work on Standard Oil, Henrietta wrote a couple of articles ${ }^{6}$ and brought to conclusion one task of long standing. In the mid-1930's she had started building a bibliography on the history of business and background materials for it. In that process she surveyed thousands of books and articles. At long last, in 1948-1949 she saw her Guide to Business History through the Harvard University Press. A monumental compilation of 5,000 references, the Guide, ever since publication, has been the starting point for every researcher in the field, has been almost equally important for general economic historians, and is now out of print.

The History of the Standard Oil Company (New Jersey) has proved to be a much more strenuous and time-consuming job than the Guide to Business History. Henrietta found her assigned share of the original research - the history of Latin-American operations of the Jersey Company - both stimulating and fascinating, though requiring examination of widely scattered materials. Before she could complete that task, however, a series of difficulties arose, difficulties which merit no exposition here. Suffice it to say that Henrietta surmounted them one by one, but the illness and later death of Professor Gras left her full responsibility, in the name of the Business History Foundation, for the completion of the project. In 1955 she breathed a sigh of relief when the first volume appeared, ${ }^{7}$ breathed still more easily a year later with the publication of the second, ${ }^{8}$ and began to feel that she could see the possibility of successful fruition of the whole project with the publication of the History of the Humble Oil and Refining Company (1959), of which she is coauthor with K. W. Porter. ${ }^{9}$ Now she is putting the final touches on

a "Plutarch's Lives' of Trade: The First Series of American Business Biographies," Bulletin of the Business Historical Society, Vol. XX (Feb., 1946), pp. 28-32; "Business History: Retrospect and Prospect," ibid., Vol. XXI (Dec., 1947), pp. 173-199. The lastmentioned was a significant contribution to the history of the field itself.

${ }^{7}$ Ralph W. Hidy and Muriel E. Hidy, Pioneering in Big Business, 1882-1911 (Harper \& Brothers).

${ }^{8}$ George S. Gibb and Evelyn H. Knowlton, Resurgent Years, 1911-1927 (Harper \& Brothers).

9 Article by-products of the Standard Oil project for Henrietta Larson have been the following: "Availability of Records for Research in the History of Large Business Concerns," Bulletin of the Business Historical Society, vol. XXII (Feb., 1948), pp. 12-21; 
the third volume of the Jersey Standard history, on which she will be listed as co-author with Evelyn H. Knowlton and Sterling Popple. Only the summary volume, which she was to have written with Professor Gras, will remain to be done. Obviously, the History of Standard Oil Company (New Jersey) will stand pre-eminently as a monument to the perseverance and scholarship of Henrietta M. Larson.

Completing the Standard Oil study will be only a part of Henrietta's activities in "retirement." At the request of the Dean of the Harvard Business School, she has continued to act as Editor of the Harvard Studies in Business History, a post she has held jointly or alone since 1948. ${ }^{10}$ Now in process of going to press is Raymond de Roover's history of the Medici Bank, and two more manuscripts are reportedly nearing final form. Neither editing chores nor writing the summary volume on Jersey Standard, if Henrietta's plans are realized, will prevent the production of some essays on the history of business. She feels sure that as a joint builder of the field she has some observations of significance to make about Business History. We should not be surprised if she would be right again.

It seems especially fitting to close this tribute to Henrietta Larson by noting the growing interest in the field to which she has devoted her life. Today we stand on the threshold of a new era and face new challenges. The following article reviews some of the obstacles and opportunities that confront us, and the remainder of this issue is devoted to the papers which explored these areas at a conference held at the Harvard Business School in October, 1961. As we grapple with the problems they raise, the quiet dedication and contributions of Henrietta should serve as an inspiration for all of us.

RALPH W. HIDY Harvard Graduate School of Business Administration

MURIEL E. HIDY Business History Foundation, Inc.

\footnotetext{
"Problems and Challenges in Business History Research with Special Reference to the History of Business Administration and Operation," ibid., vol. XXIV (Sept., 1950), pp. 120135; and "The Rise of Big Business in the Oil Industry," Oil's First Century (Boston, 1960), pp. $27-42$.

${ }^{10}$ Henrietta Larson was co-editor with N. S. B. Gras, 1948-1950, and with T. R. Navin, $1950-1955$.
} 